\title{
Understanding Teenage Motherhood through Feminist Research: A REFLECTION ON THE CHALLENGES
}

ENTENDIENDO LA MATERNIDAD ADOLESCENTE A TRAVÉS DE LA INVESTIGACIÓN FEMINISTA:

UNA REFLEXIÓN SOBRE LOS DESAFIOS

Kyla Ellis-Sloan

University of Brighton; Kes13@brighton.ac.uk

\begin{tabular}{|c|c|}
\hline Historia editorial & Resumen \\
\hline Recibido: 08-04-2014 & \multirow{4}{*}{$\begin{array}{l}\text { Este artículo se basa en un estudio etnográfico con madres adolescentes y analiza } \\
\text { cómo la investigación incorporó objetivos políticos feministas y cuestiones éticas. } \\
\text { El artículo se centra, en particular, en un asunto clave para las investigadoras fe- } \\
\text { ministas, el del poder jerárquico en el marco de la investigación, con el objetivo de } \\
\text { demostrar los desafíos y ventajas de la investigación feminista. Para mitigar las re- } \\
\text { laciones de poder se tomaron distintos enfoques, que han sido analizados y refleja- } \\
\text { dos en el trabajo. Después, el texto continúa interrogando la posición de la autora } \\
\text { como "investigadora infiltrada". El artículo muestra cómo la investigación femi- } \\
\text { nista permitió que la posición de la investigadora fuese reconocida, analizada y } \\
\text { criticada, asegurando de este modo la consistencia de la investigación que desafía } \\
\text { las nociones convencionales de objetividad. }\end{array}$} \\
\hline Primera revisión: 06-08-2014 & \\
\hline Aceptado: 03-12-2014 & \\
\hline $\begin{array}{l}\text { Palabras clave } \\
\text { Embarazo adolescente } \\
\text { Maternidad adolescente } \\
\text { Investigación infiltrada } \\
\text { Investigación feminista }\end{array}$ & \\
\hline
\end{tabular}

Abstract

\section{Keywords}

Teenage Pregnancy

Teenage Motherhood

Insider Research

Feminist Research
This paper draws on an ethnographic study with teenage mothers. It discusses how the research incorporated feminist political goals and ethical concerns. The paper focuses in particular on one key concern for feminist researchers, that of hierarchical power in the research setting in order to demonstrate the challenges and advantages of feminist research. A number of approaches were taken to mitigate power relationships and these are discussed and reflected upon here. The paper then goes on to interrogate the author's position as an 'insider researcher'. It is demonstrated here how feminist research enabled the position of the researcher to be acknowledged, analyzed and critiqued thus ensuring that research which challenges conventional notions of objectivity is robust.

Ellis-Sloan, Kyla (2014). Understanding Teenage Motherhood through Feminist Research: A reflection on the challenges. Athenea Digital, 14(4), 129-152. http://dx.doi.org/10.5565/rev/athenea.1370

\section{Introducción}

This paper draws on a $\mathrm{PhD}$ study examining the experience of teenage motherhood in order to reflect on the challenges of conducting feminist research. It provides a detailed reflection on the application of feminist principles to the research process. In particular the paper discusses approaches designed to mitigate hierarchical power in the research relationship. The paper also focuses on the researcher's personal experience of having been a teenage mother herself in order to examine the trials and tribulations of conducting 'insider' research ${ }^{1}$. There are a growing number of research articles touching on the challenges and debates related to conducting feminist research (see for

\footnotetext{
1 Insider research is research (usually ethnographic) conducted by someone "...whose biography (gender, race, class, sexual orientation and so on) gives her a lived familiarity with the group being researched..." (Griffiths, 1998, p. 361)
} 
example Armstead, 1995; Huisman, 2008 and Millen, 1997). Similarly there is a burgeoning interest in insider research (see for example Griffiths, 1998; Hodkinson, 2005; Mercer, 2007 and Mohammed, 2001). This paper brings these two areas together to demonstrate how feminist research can address some of the challenges of conducting insider research.

Kimberley Huisman (2008) argues there is a continuing need to publish papers of this ilk in order that researchers are aware of the range of challenges they may face and possible strategies for resolution. It is therefore the intention that this paper should sit alongside similar texts in order to add to the 'knowledge bank' available to feminist and non-feminist researchers alike. It provides a grounded account of feminist practices which address the advantages and drawbacks of doing feminist research in order to sit alongside more theoretical texts. In addition, this paper also aims to highlight how conducting feminist research is not a simple panacea for ethical dilemmas. Feminist discussions of research allow for honesty in the recounting of research processes and encourage reflexivity. Consequently, an account of research is offered here which did not always go as smoothly as expected. Furthermore, this paper discusses how feminist principles enabled me to interrogate my identity and influence. It then concludes by considering how, despite the challenges detailed here, utilising feminist research principles for this project was both useful and ethical. This paper therefore enables readers to see how research processes develop rather than being presented with a sanitised final account.

Before going on to discuss these issues, the paper will start by providing a brief outline of the research on which this paper is based.

\section{Setting the Research Context}

This paper draws on an ethnographic study conducted as part of my PhD. It investigated experiences of teenage motherhood in the UK. Specifically the research examined paths to motherhood by looking at key areas of decision making such as those relating to contraceptive use and the 'decision' to continue with a pregnancy. This was of particular interest because of the way in which teenage parents (and particularly mothers) are represented in the UK. Here, teenage pregnancy is presented as the outcome of a poor upbringing, promiscuity or a cynical attempt to access welfare (and sometimes all three $)^{2}$. Furthermore, teenage pregnancy is has also been argued to result

\footnotetext{
Many on the political right see teenage pregnancy as evidence of promiscuity, immorality and a defunct welfare system which encourages dependency (Almond, 2010; Pemberton, 2009). This was particularly evident during 2009 in the reaction to the pregnancy of a fifteen year old in the South of England (see for example Bracchi, 2009). The reaction was more muted from those on the left with an emphasis on inequalities and inadequate sex
} 
in poverty, low educational attainment for mother and child, ill health and poor parenting (SEU, 1999). This is despite academic work which challenges these links (see work by Lisa Arai 2003a; 2003b; 2009a; 2009b and Simon Duncan, 2007 in particular). Academic research also provides nuance to these arguments and points to socio-economic position rather than teenage pregnancy as the causal factor for these outcomes (see Ellis-Sloan, 2012, for a full discussion).

Motives, influences and constraints on the decisions of young women on their 'paths' to motherhood were therefore a prime interest of this research. The research was also concerned with young mother's interactions with government policies designed to support teenage parents. Consequently women's decisions relating to relationships, education and employment were examined. The research ultimately aimed to deepen understanding of the causes and outcomes of teenage pregnancy. Qualitative research methods were used to examine these key decisions and choices. Firstly, participant observation was conducted in three young parent support groups in the South East of England. Observations were conducted at the groups' weekly meetings for a period of between nine months and a year. After three months in the field a focus group was formed with a small group of young mothers attending one of the support groups. This was designed to act as a research advisory group (RAG) and was underpinned by feminist principles of giving voice and addressing power imbalances in the research relationship. This was then followed up with twenty-three in-depth interviews. This included one couple interview and two group interviews. Interviews were informed by a narrative approach in that questions were asked in order to get a loosely chronological account of the women's biographies. This enabled an understanding of the women's 'paths' to motherhood to emerge. Data was analysed thematically and frameworks of gender and dominant Western constructions of 'good' motherhood were employed to aid understanding. The analysis helped to show how the women variously engaged, resisted and managed social policies aimed at shaping their behaviour. Importantly, the research also demonstrated how family and mothering ideals were influential at every stage of 'becoming' a teenage mother. Furthermore, the impact of problematising constructions of teenage pregnancy (noted above) on policy interventions and experiences of young motherhood were made evident.

This paper will now go on to discuss the underpinning theoretical and epistemological position in order to demonstrate how these fed into the research process.

education rather than moralising (see for example Gardener, 2009; Toynbee, 2009). Nonetheless, most of the public, media and government furore accorded with views of the former commentators. 


\section{The Underpinning Theoretical Approach: Explaining my feminist epistemology and perspective}

This research was underpinned by my understanding of feminism as being concerned with women's lives and gendered power. Given the varied and often contested nature of feminism and feminist research, my position requires some more clarification however.

The research discussed here was grounded in experience. It is my belief that foregrounding experience enables an understanding of the lives and decisions of young mothers to emerge. Moreover, it enables counter discourses and alternative stories of teenage motherhood to be heard. I consider this to be an important aim for feminist research because of the ways in which young mothers are often presented in the public sphere. As noted above, it is often assumed that teenage motherhood is an active choice made to avoid paid employment and claim 'generous' benefits. Studies such as the one discussed here help to add nuance and further understanding of these claims. For example, whilst it is the case that the majority of women within my study were not in paid employment, many were financially supported by employed partners or parents. Those who were on benefits often discussed the struggle of surviving on low incomes. Furthermore, the reasons for not being in paid employment were linked to a desire to the 'right thing'. For most of the women, the 'right thing' was the belief that the role of the mother was to be at home with her children, at least until school age. Despite significant changes in women's roles out of the home, this traditional reading of motherhood is not out of step with dominant expectations for mothers (Lupton, 2000). It is the case, however, that expectations of teenage mothers differ somewhat from what is considered suitable for 'older' mothers. For example, teenage mothers are labelled NEET (not in education employment or training) and expected to engage with a 'reintegration officer' whose role is to return them to education or employment at the earliest opportunity ${ }^{3}$.

This research therefore challenged dominant perceptions of teenage mothers and was not 'value neutral'. Similar to feminist researchers before me, I was starting my research "from outside the dominant conceptual framework" (Harding, cited by Hirsch \& Olson, 1995, p. 204). As Sandra Harding (1992) argues however, accepting that social research is not neutral does not mean that it should not seek to be objective. To this

\footnotetext{
3 Interestingly, this study found that the desires of the women were not out of step with the demands of the professionals paid to engage them in education and employment. What was out of step however, was the timing. Many of the women were invested in finding an educational path that could work for them as mothers rather than individuals. This entailed waiting until their children were in nursery until returning to education, finding part time work that fitted around their children's needs and being a good role model through education and employment (albeit at a later stage).
} 
end she posits the idea of 'strong objectivity'. Strong objectivity is grounded in standpoint theory. Standpoint perspectives draw on Marxist arguments that the view from privileged or oppressor groups would always be partial. This is a position adopted and utilised by some feminist theorists, particularly Sandra Harding. Harding has subsequently argued that examining experience, especially experiences of marginalised groups improve objectivity as it gives a 'whole' rather than a partial view (Hirsch \& Olson, 1995). Furthermore, Harding (1992) challenges traditional definitions of objectivity arguing that rather than eradicating bias, researchers should be incorporating it into the process of knowledge production. By recognising the context of knowledge production and the social position of the researcher more ethical and transparent work is therefore possible.

Feminists who practice strong objectivity therefore "have a clear political and social commitment to strengthening the truthfulness and objectivity of knowledge claims" and take "the voices and experiences of the silenced and marginalised into account” (Brooks \& Hesse-Biber, 2006, p. 8). Harding cites working class and racial minorities as 'marginal lives' in that they have been excluded from Western conceptions of rationality (Hirsch \& Olson, 1995). Here, I would also add teenage mothers. I argue that teenage mothers are either excluded from rationality or have their rationalities for parenthood reshaped to fit commonly held stereotypes. What I mean by this is that teenage pregnancy is generally considered to be either unintended, accidental, unwanted or a mistake. Western constructions of youth do not allow for women under the age of twenty to claim a legitimate desire to mother (Ruddick, 1993). When pregnancy and motherhood is considered to be intentional the mother's rationality is considered to be linked to naivety, dysfunctional families, a 'benefits culture' or low expectations (Macvarish \& Billings, 2010). It was therefore considered that examining experiences of teenage mothers was a legitimate and fruitful way to meet the research and political aims of the study.

Whilst I utilised the concept of 'strong objectivity' and focused on experience, I stopped short from taking a strict 'standpoint' position however. Instead, I was more aligned to the approach of Liz Kelly, Sheila Burton and Linda Regan (1994) in considering experience as an important starting point for feminist analyses and not as an end in itself. I also acknowledge that experience doesn't produce an absolute truth, but what it can do however is to widen the debate and provide alternative 'stories' (Letherby, 2002). Experience is therefore still a powerful tool. Furthermore, the research was approached from a social constructionist perspective in that it challenged taken-for-granted assumptions and 'knowledge' (Burr, 1995; Pillow, 2004). As Kenneth Gergen (1999) notes, social constructionist approaches fit into theoretical perspectives 
which have a mandate to challenge the 'truth' and 'facts' of the dominant order. As such, taking a social constructionist approach accords with the feminist positioning of the researcher.

It is acknowledged, however, that taking a social constructionist approach is not without problems. A social constructionist perspective implies that there is no objective reality beyond language and construction. Whilst the invitation to challenge knowledge may have positive outcomes, this also has implications for denying experience. In the context of this research, which sought to provide voice to young mothers, this can be considered highly problematic. Nonetheless, the research did not take an extreme social constructionist perspective which can denote that reality is entirely dependent on structures of language. Instead, it was accepted that the idea that experience is either socially constructed or real is a false dichotomy (Burr, 1998). Discourse and the material world cannot be separated; it is the 'assemblage' of these two which constitutes social reality and experience (Brown, Pujol, and Curt, 1998). For example, the experiences related by the teenage mothers in this research were produced by discourses around gender and motherhood together with the material world in which the women live in, including, for instance, the 'reality' of domestic abuse or inadequate housing. By avoiding an extreme social constructionist position here, space is left for experience without denying the impact of discourse. This approach is, therefore, both pragmatic and congruent with the research aims. Furthermore, this position allows for an understanding that research processes play a part in knowledge construction rather than simply representing experience. For example, the women interviewed here were very aware of the way in which teenage pregnancy and parenthood was publically perceived. As I consequence, I approached analysis considering the women's need to present a particular 'self' to me, their 'audience' (for more discussion see Ellis-Sloan, 2014).

It was (and is) the belief of this researcher that feminism, and therefore feminist research, should be transformative. It is also considered that a focus on experience is an important means by which to do this. Experience enables sources of oppression (such as structures of gender) to be named and therefore challenged. Cultural silences around women's 'issues' such as unfulfilment in the home (Friedan, 1963) or female sexual desire (Fine, 1988) have, in the past, kept problems private. Feminist attempts to speak out and name systems of oppression such as patriarchy have opened out these areas for discussion and challenge. Speaking out about the experiences of teenage motherhood can play a similar role. As noted above, negative constructions, stereotypes and assumptions are commonplace in public discussions of teenage pregnancy and parenthood. As a result, teenage pregnancy has been described as a contemporary scapegoat and moral panic (Duncan, Edwards and Alexander, 2010; Kelly, 1996; Selman, 
2003). The impact of this is felt in the stigmatisation of teenage mothers (Ellis-Sloan, 2014), the exclusion of young parents from much needed support services (Craig \& Stanley, 2006; de Jonge, 2001) and in the production of policies which can compound rather than ameliorate the challenges of young parenthood (Duncan, 2007).

This emphasis on structure noted here implies an affiliation to areas of feminism traditionally associated with the 'second wave' movement. We are, arguably, in an era of postfeminism ${ }^{4}$ however. Women are encouraged to think that sexism is no longer a significant barrier to success and individual reflection and hard work will deal with any residual issues. Structures of oppression (such as patriarchy) are rarely part of the lexicon of postfeminism. This feminist approach is epitomised by Naomi's Wolf's 'power feminism' (Wolf, 2004) or Sheryl Sandberg's exhortation for women to 'lean in' (Sandberg, 2013). My own feminist approach, however, accords with writers such as Rosalind Gill, Joanne Baker and Angela Mcrobbie. These theorists critique postfeminism as having taken feminism 'into account' whilst simultaneously repudiating the feminist movement (Mcrobbie, 2009). Structures of inequality are downplayed and women are encouraged to think of naming sexism as akin to seeing oneself as a dependent or a victim (Baker, 2010). This 'mode' of feminism is therefore argued to have been depoliticised and replaced with a focus on women's individual power to earn and consume which accords with both capitalist and neoliberal sensibilities (Gill, 2007). As a result, women often find it difficult to recognise or name sexism (Pomerantz, Raby \& Stefanik, 2013) and we are witnessing a "renewed institutionalisation of gender inequity and the re-stabilisation of gender hierarchy" (Mcrobbie, 2007, p. 718).

In accordance with these authors, I see structure as an important means of understanding continuing gender inequality. In addition, I see feminism as more than a tool to increase women's earning power and participation in employment. As Angela Mcrobbie (2009) acknowledges, postfeminism works with the status quo rather than offering any critique of culture or capitalism. Consequently, contemporary feminism limits equality, and indeed citizenship, to that of employment and consumption. This was a particularly pertinent concern for this research. Dominant ideals of citizenship have led to young mothers being asked to prioritise their earning potential over their parenting potential. Whilst I do not wish to see a return to a time where motherhood was considered the sole destiny for women, a feminism which sees equality and participation only in terms of earnings is equally limiting. Furthermore, motherhood still retains a contradictory place in society where it is valued in theory but not supported in practice (Phoenix, 1991). As a consequence, young women who choose motherhood

\footnotetext{
${ }^{4}$ The term 'postfeminism' is used here to describe popular contemporary feminism which accords with a Third Way political economy and neoliberal sensibilities rather than as a term which depicts an era 'after' feminism (See Genz \& Brabon, 2009) for more discussion of this reading of contemporary feminism).
} 
are often seen as making a poor decision rather than a different decision and are not given adequate support.

Foregrounding the experiences of young mothers was therefore considered to be an important and valid means to challenge the 'accepted knowledge' surrounding teenage pregnancy. This fitted into wider feminist aims of opening up areas of silence and naming structures of oppression. Furthermore, this linked to my own personal commitment to social justice. The following section will now go on to discuss how these feminist principles impacted on methodological decisions.

\section{How Feminist Work Influenced the Research Approach: A Concern with Power}

This research was particularly influenced by concerns raised by feminists with regards to hierarchical power relationships. Judith Preissle (2007, p. 521) notes that feminists enter the research process with a keen awareness of issues of power, often seeking to 'disturb or dismantle conventional arrangements'. As has been discussed here, this was the approach I was taking to the research topic. In addition, concerns with power were also written into the research process. This section focuses on the approaches used to try and address this issue. It is also acknowledged here that issues raised by feminist researchers are not easily remedied and so enacting feminist principles is not always straightforward. Consequently, this section also reflects on the some of the challenges I faced in attempting to mitigate the effects of power in the research setting.

Several strategies were used to address the hierarchical power relationship between myself and my participants, firstly, participatory research methods. My initial thought here was that these could empower young parents to have an active voice in the research and a say in their own representation. As marginalised young people, I also considered that this process could put young parents in a position as valuable and experienced knowers of their own lives (Schostak \& Schostak, 2007). Consequently, I set up a research advisory group (RAG) in order to 'democratise the research process' (Kelly et al., 1994).

After three months of conducting observation work I approached four ${ }^{5}$ young women and requested their involvement in co-designing interview questions. At our first meeting, the women and I sat and shared our 'stories'. We talked about how we

5 Only three of the four women turned up to the first meeting and only two at the second. As I discovered th roughout the project, I (and my research) was pretty far down the women's often long list of priorities and concerns. 
met the fathers of our children, contraception use, childbirth and being a mother. We met up again a fortnight later and, as with the initial meeting, I provided bus passes, food and toys. This time we organised our previous discussion chronologically and fleshed out some of the key points in our narratives. These then became the questions and prompts I used in interviews designed to guide participants through their biographies. Doing this also led me to use a narrative style of interviewing. Furthermore, it alerted me to areas I had not previously considered as topics for the interview; for example, maintaining and managing access with an ex-partner.

My plan at this point was to return to the RAG in order to discuss findings, repre sentation and dissemination. Despite my intentions, these two meetings were the only times I engaged with participatory methods. The ethical review process which I was obliged to follow with my host university and the local authority took so long that my time in the field had become severely restricted. This, alongside the period I was allotted to complete my thesis, meant the time needed to properly invest in the RAG was no longer available. In addition, returning to the RAG after fieldwork was completed was made difficult by significant policy changes in the area of teenage pregnancy support. These changes meant that two of the groups I had been working with were closed down and the third was taken over by the local Primary Care Trust ${ }^{6}$. As a consequence my connections in the field (both parents and workers) were dispersed and contact was lost. Care therefore needs to be taken not to claim too much from this small inclusion of participatory methods. Although, the RAG meant the research was, in part, framed by participants, ultimately I was in control of the analysis and writing up of accounts. Asking for young parents' input and opinions at the outset, on its own, did not significantly diminish my power in setting the research agenda.

Secondly, I attempted to equalise the research relationship by engaging with strategies of reciprocity. It is recognised that reciprocity of the kind described by Michelle Fine, Lois Weis, Susan Weseen and Loonmun Wong (2000) (advocacy, report writing and long-term involvement) and many others including Kimberley Huisman (2008) is ideal. The reality for me, however, was that the time and funding limitations of studying for a $\mathrm{PhD}$ whilst also teaching restricted my ability to engage in this way. I was however, able to provide some assistance in the running of the support groups. For instance, I helped to set up before the weekly sessions and cleared away afterwards. I took on tasks the other leaders did not have time for such as filming activities and taking feedback for funding reports. I often held and fed children so that the mums (my participants) attending the group could have some time to themselves or with their

\footnotetext{
${ }^{6}$ Primary Care Trusts (or PCT's) were administrative bodies working under the NHS (National Health Service) responsible for commissioning health services. Until 2011 they also directly provided community health services.
} 
friends. I also provided activities I had picked up from my time as a youth group leader, and for a limited period I sat on the steering committee for one of the groups.

I also took on board the work of Ann Oakley (1981) and Janet Finch (1993) and sought to take a reciprocal approach during the interview process by sharing my experiences and thoughts when asked. By interviewing in this way I was seeking to put myself 'on the same plane as my participants' (Huisman, 2008, p. 387) and build a 'rapport'. As these authors have also pointed out, however, working in this way can increase the risk of exploitation. A relationship which is more personal than professional may increase the vulnerability of participants. For instance, many of the women in my research were happy to tell me their stories and answer any questions I asked whilst showing little interest in consent forms, information sheets or what exactly it was I was going to do with their stories. Finch (1993) similarly found her participants demanded few assurances about confidentiality and her intentions. It is therefore important that strategies such as reciprocity are used in conjunction with the ethical foundations of feminist epistemology (Finch, 1984 cited in Lee, 1993).

Thirdly, I placed myself as an individual rather than simply a researcher at the heart of the study. Self-disclosure involves opening out researcher's interests and experiences in order to break down the subject/object split (Letherby, 2002). As Ruth Behar (1993, p. 273) notes; "we ask for revelations from others, but we reveal little or nothing of ourselves; we make others vulnerable, but we ourselves remain invulnerable". Selfdisclosure arguably addresses this vulnerability by placing the researcher's accounts alongside those of the participants. Both party's stories are therefore left open for interpretation and analysis by the reader. The limits to this as a strategy to address power should also be acknowledged however. Participants may have the power to withhold or distort information (Wolf, 1992) but he researcher retains the decision as to what they write and who they write about (Finch, 1994). Furthermore, feminist work which encourages personal involvement and investment may be more ethically precarious (Stacey, 1988). Participants may be more likely to disclose information if the relationship appears more personal than professional. As Judith Stacey (1998) argues, we need to take responsibility for our research practices and be rigorously self-aware whilst acknowledging the limitations of our endeavours.

As will be discussed in more detail below, my position as having been a teenage parent and all that that meant for the research became part of the final thesis. It was important, however, to remain aware of my position but also of the differences between my own experience and those of my participants. For instance, although I had been a teenage parent, I was eighteen when I gave birth to my daughter. This meant that I was (rather arbitrarily) exempt from the involvement of social workers and reintegra- 
tion officers ${ }^{7}$. A few months earlier and the demands of these professionals would have featured heavily in my life, much like many of the participants in my study. Furthermore, when I became a single parent not much later, I had a family with both the resources and the will to support me. This meant I was able to move to a house in a better area and was helped with babysitting for both social and educational pursuits. I was therefore sheltered to a certain extent from some of the challenges of youthful parenting. This is not to say I did not face challenges, merely that it is important to recognise that mine were very often different to those of my participants. I learnt therefore to be critically aware of my experiences and to contextualise the differences between myself and my participants rather than simply documenting them.

Furthermore, care was taken not to let my story and self-disclosures overshadow and therefore misrepresent the voices of my participants. It would be all too easy to let my voice sit alongside those who publicly claim they made a success of teenage parenthood by sheer hard work. For example, Teresa K. Kim-Tenorio used her first judicial address to speak about her experiences as a teenage parent stating that, "there are many paths [to success] that only require one thing: determination" (Kim-Tenorio, 2014, paragraph 16). Whilst these types of positive accounts can temper the venomous stories we are used to hearing about teenage mothers, they also obscure the fact that many young parents also need safe and secure housing and reasonable financial support in order to 'succeed'. As Michelle Fine, Lois Weis, Susan Weseen and Loonmun Wong (2000) caution, writing in the self can lead to the researcher's voice becoming authoritative and silences the experiences of the participants. Again, a critical lens had to be employed so my own voice did not silence those of the women I was researching with.

Finally I focused on the potential damage of misrepresentation. As part of my final thesis I was critiquing some of New Labour's support policies for teenage mothers. In particular I was concerned that their focus on education and employment for young mothers undermined the women's roles as parents. Yet by writing this critique I was adding my voice to those from the political right who claim that the money spent on teenage pregnancy and parenting was wasted ${ }^{8}$. Whilst I wished support to be respectful of the women's desire to mother and to move away from lazy stereotypes, I certainly did not want the wholesale removal of support systems and personnel. As Fine et al. (2000, p. 122) note of their research, "our responsibility...was not to feed the dismantling of the state by posing a critique of the public sector as it has been, but inste-

\footnotetext{
Reintegration officers were introduced as part of the Teenage Pregnancy Strategy in 1999. They provided one-toone support for pregnant and parenting teenagers of school age to remain in education.

8 For example The Times reported; "A ten-year strategy costing millions of pounds to cut the "shameful" number of teenage pregnancies in Britain has failed to make any serious impact” (Bennett \& Hurst, 2010)
} 
ad to insist on a state that serves its citizenry well and responsibly". There is a need then for researchers to paint a picture of how it should be rather than simply how it is wrong. In the context of a $\mathrm{PhD}$ thesis, this is limited to recommendations for alternative policies, approaches and further research. Creative dissemination and further research can be beneficial however. Following the completion of the thesis (and the closure of the groups noted above) I returned to the field in order to collect data on the impact of the groups and their subsequent closure. Plans are being made to work collaboratively with professionals in the field who work with teenage parents. It is hoped that the data from this project and the thesis preceding it will inform newly formed service provision for young parents.

This section has demonstrated how feminist concerns with hierarchical power relationships in the research setting influenced research decisions. It also illuminated some of the challenges of incorporating these principles into research practice. When reflecting on the research there was one challenge which, for me, encapsulated the debates, advantages and challenges involved in conducting feminist research. That is, researching as an 'insider'. The following section will now go on to reflect on what this meant for the research and how feminist approaches provided both support and a challenge to my positioning as an 'insider' researcher.

\section{The Challenges of Conducting Feminist Research: Rese- arching as an 'insider'}

As discussed above, feminist research openly challenges the notion that a researcher is or should be a neutral observer. Instead, many feminists 'write in' the researcher's personal position and investment thereby making the subjectivity of the researcher part of the process of knowledge creation. Acknowledging the personal biography of the researcher is a valuable part of this process of reflexivity (Letherby, 2002) but as Andy Bennett (2003) argues however, to simply note the position of the researcher is not sufficient. Critical engagement is required in order to analyse its impact on the setting and participants. In the case of my research this was about asking questions of my own experience and its influence on my reading of the data, contextualising my experiences and those of my participants. It is argued that this practice can make the data more honest as well as allowing for scrutiny to make potential biases explicit (Maynard, 1994). This section relates some of the critical engagement and personal scrutiny I employed as I considered my subjectivity.

I entered the research with a strong sense of myself as an insider. To me, having been a teenage parent meant I had a unique status as an insider researcher. My fee- 
lings here were bound up with the strength in which I identified as a teenage mother. Becoming pregnant at eighteen was a defining moment in my life. My pregnancy was reacted to with horror followed by a series of questions. Was I going to keep it? How was I going to support myself? Did I realise that I would be tied down for at least eighteen years? What about my life, did I not want to do anything for me? Despite these questions being just as valid when I fell pregnant again in my thirties, the only reactions I received were congratulatory. The inference is clear. Having a baby in your thirties is normal, everything will work out fine. Having a baby at eighteen is a decision you must justify and one you are considered not have thought through.

For the early years of my daughter's life, being a 'teenage mum' was a dominant feature of my identity. For many years, when people learnt the age of my daughter, I was questioned about being a teenage mother and was subject to many assumptions. Relative strangers would ask me if I was still with the father. People seemed intrigued by how my parents, and particularly my mother, had reacted to my pregnancy. On one memorable occasion a mother on the school playground asked me in a sneering voice if I was off home to 'put my feet up' after I had dropped my daughter off. These kinds of questions, assumptions and 'sneers' accompanied many of my dealings with authority figures and encounters with other (older) mums on the 'toddler circuit'. This not only reinforced my sense of self but also my feeling that being a teenage parent was considered as something negative. Consequently I identified as a teenage mother long after I left my teenage years. Furthermore, because of the ways in which this label was, I felt, applied negatively, I spent many years trying to avoid being defined as such by others.

In embarking on the research process, my experience of having been a teenage parent came to the fore again. Many discussions were had with supervisors, ethics committees the leaders of the young parents groups as to what this might mean for the research. The leaders' recognition of me as a teenage parent was key to my being allowed to conduct research at one site. Previously, they had been reluctant to let researchers have access. My personal history, however, reassured them that I would do justice to the stories of the young parents. Upon entering the field, group leaders drew on my experiences as a teaching aide. At one research site I spent some time sitting in on a young parents' ante-natal group. The leader often brought some of the young mums from the post-natal group in to talk about their experiences of pregnancy, childbirth and parenting. I was utilised in much the same way. In a later session on childbirth, the midwife in charge asked me to reflect upon my experience of pregnancy and birth as a young mother. 
The strength with which I identified as a teenage mother meant that I assumed my participants would also identify with me as such. As Fine et al (1994), note we should problematise the relationship between the researcher and the researched. However, it was only after an exchange with one of my research supervisors where he told me I was no longer a teenage mother and asked me why I continued to see myself as such, did I start to question my assumption and apply the 'critical lens' referred to above. Going back over the interview transcripts and my observation notes I started to consider that I had indeed overestimated the extent to which my participants identified with me as an 'insider'.

There were instances in the research where I had initially felt I was connecting with the parents on the basis of my status as a teenage mother. For example during my interview with Nancy;

Nancy: Can I ask you a personal question?

Kyla: Yeah go on.

Nancy: Since you've had your child and split up with him, have you met any serious partners since...See, I feel really lonely that's the only thing now... I've got my friends and everything but I need a cuddle, a bit of attention.

(Nancy, personal interview 21-05-2008)

I first thought that Nancy was drawing on my experience of having been a young parent. When I returned to the transcript and looked at the interview as a whole, I felt very differently about how Nancy saw me however:

Nancy's sister: So have you got a daughter now as well?

Kyla: Yeah I've got a ten year old, nearly eleven. I had her when I was eighteen.

Nancy: At least you were a bit older.

Kyla: Yeah, I was the family scandal though!

Nancy: At least you were a bit older though.

Kyla: Yeah, I had done my GCSE's. I flunked out of college though, it was just before I took my A levels and I failed them.

Nancy: At least you done those, I didn't get to do them.

Kyla: Yeah, well no because I failed them.

(Nancy, personal interview 21-05-2008).

The above excerpt shows Nancy rejecting my experience of being a teenage parent. Nancy had been sixteen when she had her daughter. For her, my having been 
eighteen was not the same. The extract also demonstrates how I was trying to hold onto my identity as a teenage parent. In retrospect, this illustrates the significance I, rather than Nancy, gave to being an insider. Having made this recognition I returned to the data and could find no overt incidence where I was viewed as an 'insider' by the participants. Furthermore, I began to consider that there were aspects of my identity which created substantial differences between us, for instance my relative age, education, and professional status.

Whilst I cannot claim to have been an 'insider' there were experiences I shared with the young mums. For example, my experience as having been a single parent appears to have been relevant to Nancy (see above). It may therefore be more appropriate to define myself as having had a 'shared biography' with my participants. That is, I shared a similar life course to that of participants which enabled a significant amount of understanding. Defining myself as having a 'shared biography' also has the advantage of not limiting shared experiences to those related to being a teenage mother. Furthermore, it also allows for the very different experiences I had to many of my research participants. It is this 'shared biography' which therefore needs interrogating as to its effect on the research.

Particular aspects of a 'shared biography' were helpful to the rapport and relationships I built up with the young women. My identities as a mother, a woman and as being relatively 'young' appeared to be particularly meaningful to them. My experiences as a mother (separate to being a 'teenage mother') were called upon many times. My advice was sought, as were my 'skills' in holding, feeding and entertaining children. My position as a woman was particularly important. In the first instance, I was told I would not have been permitted access to two of the groups had I been male. My gender also aided identification and rapport in conversations and interviews. Sue Wise (1987, cited in Lee, 1993), argues that a mutual understanding cannot be assumed solely on the basis of gender. Nevertheless, it is difficult to see how my being female could not have been helpful. For instance; it was particularly important in discussions during participant observation on gender roles and housework divisions. My age was also significant. Whilst conducting fieldwork I was still in my twenties. Although this was a gap of around ten years, it was a bracket which allowed for shared references. Clothes, pubs, clubs and music all formed a familiar basis for conversation. One young woman succinctly summed this up stating: "you're quite an easy person to talk to because you're like young and you seem closer to us rather than if we had to talk to some old bag" (Rachel, personal interview, 20-04-2008).

\footnotetext{
9 All names have been changed to protect identity.
} 
Defining the researcher as having a shared biography rather than being an insider doesn't prevent common experiences being acknowledged. Indeed, I sometimes recognised my own behaviour in that of the women I was observing. For example, there was a familiar sense of 'othering' and defensiveness in many of the women's accounts of events in their lives. For example, with one young woman whose baby had been taken into care when she was only a few months old. The mother had had very little time to adjust to being a mum and possibly as a result, appeared somewhat lost. She was only allowed supervised access with her daughter and some of this took place at one of the support groups. The access supervisor and the workers were not there to scrutinise her. They would, however, be consulted when the decision had to made whether to return the baby or not. As a consequence the mother was parenting under the gaze of professionals with considerable power. Her reaction to this was to show that she was a 'good' parent in the best way she knew how. She had begun to rely on a disciplinarian method of parenting. Barbara Hanna (2001) argues that this is a common parenting strategy amongst teenage mothers. I don't necessarily disagree, but my experience and research leads me to argue that this is also often linked to the stigma and judgment (perceived or real) of being a teenage mother. My own experience also impacted on my reaction to what I observed. I felt that the mum was not enjoying this role but felt unable to assume another one. So I started a game with her daughter and invited her to play with her mum. Thus encouraged, and with the scrutiny shared with me, she began to join in and play with her daughter. I analysed this incident (and a number of others) with reference to existing academic work and theory around stigma but also by linking it to my own experiences. I cannot tell whether I would have fully understood her behaviour (or reacted in the way I did) without our shared biography. I suspect not however.

As with the use of feminist approaches to challenge power in the research setting, working with and interrogating my 'shared biography' was challenging. Firstly because, regardless of how the women saw me, I felt deeply connected to my participants and their experiences. There were points during the research process where this impacted on the way I felt about the problematisation of teenage parenthood. I had always understood it to be a contested issue but the more I identified with the women, the more I started to lose sight of the intricacies of the debate. I found acknowledging some of the difficult things I saw challenging because I found them hard to reconcile with my desire to critique stereotypes. This was not helpful and made for partial data. Reflexive practices and good supervision, however, helped to see where I had started to put on the blinkers and rectify the process. Furthermore, a feminist lens was helpful in making sense of what I saw rather than simply denying its occurrence. So with the case of the young woman above, I didn't deny or write out her mothering practices, 
but I did seek to understand and contextualise it. In this way I was able to provide a more nuanced account of the experience of teenage parenthood.

Secondly, highlighting the position of the researcher within the research requires levels of self-disclosure which are not always comfortable. I often shared my experiences with participants but the readiness with which I share these as part of an academic critical reflection has not been as easy. Without a pseudonym to hide behind, exposing 'the self' can be a difficult and painful process. This required acknowledging something which I had (publically at least) spent years trying to hide. In addition, despite my understanding of feminist critiques of neutrality and objectivity, I was aware that others (especially outside of the academy) still hold onto positivistic ideals. Consequently, I did not want my experiences to undermine my participants or my arguments.

Thirdly, and relatedly, the emotional aspects of researching in areas of shared experience are difficult. It is not uncommon that social researchers experience emotional reactions during field work (see for example Gilgun, 2008; Hubbard, Backett-Milburn \& Kemmer, 2001; Rager, 2005). Furthermore, as Helen Sampson, Michael Bloor and Ben Fincham (2008) note, research may become more emotional risky for the researcher when embarking on research guided by feminist principles. Prior to starting the research, I had been made aware that qualitative research in such a personal area may be challenging. Nevertheless, I underestimated the impact that some of the women's stories would have on me. During fieldwork, two young women had their young children removed by social services. One of these cases resulted in a suicide attempt. The distress this caused to the young women involved is almost unimaginable. As a researcher, being a powerless observer was extremely difficult to deal with. Nothing in my own experience came close to the horror of having my child taken. Nevertheless, as I immersed myself in the field and the literature, I began to revisit memories of when I became pregnant. I was unprepared for the extent to which the research prompted me to re-evaluate my own past. Reflexive accounts such as those by Kathleen Rager (2005) and Jane Gilgun (2008) helped to allay feelings of weakness. This literature provided a less sanitised version which fitted more closely with my own feelings and internal debates.

Ironically, however, it was the research and $\mathrm{PhD}$ process itself which caused me to finally move on from the label of teenage mother. One of the groups I was observing was led by three women, two of whom were close to my own age who had also had children as teenagers. The third was a kind and charismatic psychologist who had been working with teenage parents for many years. These factors meant this group came to mean more to me than simply a research site. I increasingly found myself en- 
joying my time there and looking forward to the meetings. Not only this, I found that the group often left me feeling more positive about my own identity. One of the key successes of the group was the non-judgemental and supportive atmosphere. The mums were respected as knowing parents and women. Age was not a factor. Furthermore, the women provided vital emotional, financial and caring support to each other. This was something which I benefitted from as I too was accepted and supported unquestionably. I did not anticipate nor seek this outcome and I remain unreservedly grateful.

\section{Concluding Thoughts}

This paper has highlighted some of the challenges I experienced in enacting feminist principles as part of the research process. Given the critique I have levied at myself and my work, there are some justifiable questions which require addressing here. Firstly, if feminist research is about making a challenge and invoking change, has this research achieved that? The resulting thesis and publications which have come out of the research make an important contribution to a debate which questions the problematisation of teenage pregnancy and motherhood. As such, the work adds weight to a growing number of academics who seek justice for young mothers. Nonetheless, the audience for such material is limited. Whilst my contribution speaks to an important academic debate, the research also has value for service providers working with young parents. Findings therefore need to be disseminated beyond the academy. That is not to say however, that only policy change and service provision can be considered as legitimate; attitudinal change is also important. As part of my undergraduate teaching I provide a number of lectures based on my research all of which contain significant challenges to dominant thinking about teenage pregnancy. I have, on numerous occasions, had teenage parents in the lectures who have come to me afterwards and spoken about the relief they felt at hearing a different 'story' for a change. I have had students express surprise and challenge me on my lecture material as well as those who tell me they will now think differently about teenage parents. Whilst evidence here remains anecdotal, the ensuing debates in seminars and the airing of dissenting voices are nonetheless important. As Lisa Arai points out that "most people's perceptions of pregnant and parenting teenagers derive entirely from media" (2009b, p. 39, emphasis in original), challenging this dominance in a number of forums therefore remains vital.

Secondly, this research can be defined as feminist research because of its focus on women's experiences of gender and power. In doing so it challenged the status quo and contributed to an important debate. Aside from the area of study however, given the critiques and limitations discussed here, is it fair to define this research as feminist 
research? When I started my fieldwork I wholeheartedly believed in the potential of feminist research principles to deal with research issues. Like Huisman (2008) however, I soon found that the $\mathrm{PhD}$ process is not set up for this way of working. I too discovered that participatory methods, reciprocal ways of working and disseminating practices beyond the academy needed to be embedded in the process from the beginning. In addition, more time, money and investment from me and my institution was needed. As a result I was ill-prepared and sometimes felt I was playing lip service to an ideal rather than conducting feminist research. Nonetheless, the purpose of a $\mathrm{PhD}$ needs to be remembered here. Beyond career progression, it is also about learning how to do research. In my case it was about learning how to conduct ethical feminist research. The lessons I have learnt through reflecting on the gains, mistakes and limitations of this research will be incorporated into future practice and are therefore valuable.

Thirdly, and finally, what advantages did feminist research principles bring to this research project? Feminist research demands sensitivity for research participants. Throughout the research, the needs and priorities of the young women were at the forefront. Whilst in the field, I engaged with reciprocal practices and placed myself in the heart of the research alongside my participants. Consequently, an awareness of feminist research principles helped the research work for and with the participants. I also engaged in a reflexive and critical process ensuring that I learn from my participants, my actions and the research experience. This was especially important in enabling me to interrogate the impact of being (or not being) an 'insider' researcher. Feminist research not only allowed the position of the researcher to be acknowledged but also for it to be analysed and critiqued. As a consequence, the research was more robust. I consider, therefore, that in this case feminist principled research methods and approaches have been both ethical and useful.

This paper has provided an account of the use of feminist methods which has included the challenges inherent in taking this approach. In doing so it has demonstrated that taking a feminist approach is not a straight forward solution but requires personal interrogation and critique as well as significant investment. Importantly, this paper argues that when we reduce methods to tick box exercises we fail to do justice to our participants or the production of knowledge. Taking a feminist approach enables us to think much more critically about methods, research approaches and our own position. Furthermore, rather than seeing challenges such as those outlined here as 'failures' we need to reframe these as provocations to further thought and critique as to how we can do 'better' research. It is a feminist insistence on reflection and ethical conduct which enables this. Consequently, even where trials and challenges in con- 
ducting feminist research exist, conducting research in accordance with feminist principles is a valuable and ethical endeavour.

\section{References}

Almond, Brenda (2010, February 26). We'll never end our teenage pregnancy epidemic until we admit what's REALLY causing it. The Mail Online. Retrieved from: http://www.dailymail.co.uk/debate/article-1253631/BRENDA-ALMOND-Wellend-teenage-pregnancy-epidemic-admit-whats-REALLY-causing-it.html

Arai, Lisa (2003a). Low expectations, sexual attitudes and knowledge: Explaining teenage pregnancy and fertility in English communities. Insights from qualitative research. Sociological Review, 51(2), 199-217. http://dx.doi.org/10.1111/1467-954X.00415

Arai, Lisa (2003b). British policy on teenage pregnancy and childbearing: the limitations of comparisons with other European countries. Critical Social Policy, 23(1), 89-102. http://dx.doi.org/10.1177/026101830302300105

Arai, Lisa (2009a). What a Difference a Decade Makes: Rethinking Teenage Pregnancy as a Problem. Social Policy and Society, 8(2), 171-183. http://dx.doi.org/10.1017/S1474746408004703

Arai, Lisa (2009b). Teenage Pregnancy: The making and unmaking of a problem. Bristol, Policy Press.

Armstead, Cathleen (1995). Writing Contradictions: Feminist Research \& Feminist Writing. Women's Studies International Forum, 18(5-6), 627-636. http://dx.doi.org/10.1016/0277-5395(95)80099-B

Baker, Joanne (2010). Claiming Volition and Evading Victimhood: Post-Feminist Obligations for Young Women. Feminism and Psychology, 20(2), 186-204. http://dx.doi.org/10.1177/0959353509359142

Behar, Ruth (1993). Translated Woman: Crossing the Border with Esperanza's Story Boston, MA: Beacon Press.

Bennett, Andy (2003). The use of insider knowledge in ethnographic research on contemporary youth music scenes In Andy Bennett; Mark Cieslik \& Steven Miles (Eds.), Researching Youth (pp. 186-200). London: Palgrave.

Bennett, Rosemary. \& Hurst, Greg (2010, February 24). Ministers admit failure over cutting 'shameful' teenage pregnancies. The Times. Retrieved from: http://www.thetimes.co.uk/tto/news/politics/article2030992.ece

Bracchi, Paul (2009, May 22). Special investigation: The streets where Alfie, 13, grew up offer a disturbing glimpse of the moral anarchy engulfing Britain. The Mail Online. Retrieved from: http://www.dailymail.co.uk/news/article1186764/Special-investigation-The-streets-Alfie-13-grew-offer-disturbingglimpse-moral-anarchy-engulfing-Britain.html

Brooks, Abigail \& Hesse-Biber, Sharlene Nagy (2007). Feminist Research Practice. Thousand Oaks: Sage. 
Brown, Steven., Pujol, Joan \& Curt, Beryl (1998). As One on the Web: Discourse, materiality and the place of ethics. Ian Parker (Ed.) Social Constructionism, Discourse and Relativism (pp. 75-91) London: Sage Burr, V. (1995). Social Constructionism. London: Routledge.

Burr, Vivian (1998). Overview: Realism, Relativism, Social Constructionism and Discourse. In Ian Parker (Ed.), Social Constructionism, Discourse and Relativism (pp. 13-27). London: Sage

Craig, Gary \& Stanley, Nicky (2006). Visibility, Immobility and Stigma: Young People's Use of sexual Health Services in Rural Areas. Children and Society, 20, 171182. http://dx.doi.org/10.1002/CHI.880

Duncan, Simon (2007). What's the problem with teenage parents? And what's the problem with policy? Critical Social Policy, 27(3), 307-334. http://dx.doi.org/10.1177/0261018307078845

Duncan, Simon ; Edwards, Rosalind \& Alexander, Claire (2010). What's the Problem with Teenage Parents? In Simon Duncan, Rosalind Edwards \& Claire Alexander (Eds.), Teenage Parenthood: What's the problem? (pp. 1-24). London: The Tufnell Press.

Ellis-Sloan, Kyla (2012). Becoming a Teenage Mother in the UK. Unpublished PhD disertation, University of Brighton. Retrieved from: http://ethos.bl.uk/OrderDetails.do?did=2\&uin=uk.bl.ethos.590074

Ellis-Sloan, Kyla (2014). Teenage Mothers, Stigma and their 'Presentations of Self'. Sociological Research Online, 19(1), 9. http://dx.doi.org/10.5153/sro.3269

Finch, Janet (1993). 'It's great to have someone to talk to': Ethics and politics of interviewing women. In Martyn Hammersley (Ed.), Social Research: Philosophy, Politics and Practice (pp. 166-180). London: Sage.

Fine, Michelle (1988). Sexuality, Schooling, and Adolescent Females: The Missing Discourse of Desire. Harvard Educational Review, 58(1), 29-54.

Fine, Michelle (1994). Working the hyphens: Reinventing self and other in qualitative research. In Denzin, Norman K \& Yvonne S Lincoln (Eds.), The Handbook of Qualitative Research (pp. 70-82). Thousand Oaks, CA: Sage.

Fine, Michelle., Weis Lois., Weseen, Susan \& Wong, Loonmun (2000). For Whom? Qualitative Research, Representations, and Social Responsibilities. In Norman K Denzin, \& Yvonne S Lincoln (Eds.), The Handbook of Qualitative Research $\left(2^{\text {nd }}\right.$ Ed., pp. 107-132). Thousand Oaks, CA: Sage.

Friedan, Betty (1963). The Feminine Mystique. London: Victor Gollancz.

Gardener, Richard (2009, February 17). The Big Question: Why are teenage pregnancy rates so high, and what can be done about it? The Independent. Retrieved from: http://www.independent.co.uk/extras/big-question/the-big-question-why-areteenage-pregnancy-rates-so-high-and-what-can-be-done-about-it1623828.html

Genz, Stéphanie \& Brabon, Benjamin (2009). Postfeminism: Cultural Texts and Theories Edinburgh: Edinburgh University Press.

Gergen, Kenneth (1999). An Invitation to Social Construction. London: Sage. 
Gilgun, Jane (2008). Lived Experience, Reflexivity, and Research on Perpetrators of Interpersonal Violence. Qualitative Social Work, 7(2), 181-197. http://dx.doi.org/10.1177/1473325008089629

Gill, Rosalind (2007). Postfeminist media culture: elements of a sensibility. European journal of cultural studies, 10(2), 147-166. http://dx.doi.org/10.1177/1367549407075898

Griffiths, Alison (1998). Insider / Outsider: Epistemological Privilege and Mothering Work. Human Studies, 21(4), 361-376. http://dx.doi.org/10.1023/A:1005421211078

Hanna, Barbara (2001). Negotiating Motherhood: The struggles of teenage mothers. fournal of Advanced Nursing, 34(4), 456-464. http://dx.doi.org/10.1046/j.13652648.2001.01774.x

Harding, Sandra (1992). After the Neutrality Ideal: Science, Politics, and "Strong Objectivity". Social Research, 59(3), 567-587. Retrieved from: http://www.jstor.org/stable/40970706

Hirsch, Elizabeth \& Olson, Gary (1995). Starting from Marginalised Lives: A Conversation with Sandra Harding. $7 A C, 15(2), 193-225$. Retrieved from: http://jaconlinejournal.com/archives/vol15.2/hirsch-starting.pdf

Hodkinson, Paul (2005). 'Insider Research' in the Study of Youth Cultures. Fournal of Youth Studies, 8(2), 131-149. http://dx.doi.org/10.1080/13676260500149238

Hubbard, Gill., Backett-Milburn, Katheryn \& Kemmer, Debbie (2001). Working with Emotion: Issues for the researcher in fieldwork and teamwork. Social Research Methodology, 4(2), 119-137. http://dx.doi.org/10.1080/13645570116992

Huisman, Kimberley (2008). "Does this mean you're not going to come visit me anymore?": An inquiry into an ethics of reciprocity and positionality in feminist ethnographic research. Sociological Inquiry, 78(3), 372-396. http://dx.doi.org/10.1111/j.1475-682X.2008.00244.x

de Jonge, Ank (2001). Support for teenage mothers: a qualitative study into the views of women about the support they received as teenage mothers. Fournal of Advanced Nursing, 36(1), 49-57. http://dx.doi.org/10.1046/j.13652648.2001.01942.x

Kelly, Deirdre (1996). Stigma Stories: Four Discourses About Teen Mothers, Welfare, and Poverty. Youth and Society, 27(4), 421-449. http://dx.doi.org/10.1177/0044118X96027004002

Kelly, Liz., Burton, Sheila \& Regan, Linda (1994). Researching Women's Lives or Studying Women's Oppression? Reflections on what constitutes feminist research In Mary Maynard \& Jane Purvis (Eds.), Researching Women's Lives from Women's Perspectives (pp. 27-48). London: Taylor and Francis.

Kim-Tenorio,Teresa (2014) A message to teenage mothers Saipan Tribune: Garapan. Retrieved from: http://www.saipantribune.com/index.php/c2a8f947-1dfb11e4-aedf-250bc8c9958e/

Lee, Raymond M. (1993). Doing Research on Sensitive Topics. London: Sage. 
Letherby, Gayle (2002). Claims and Disclaimers: Knowledge, Reflexivity and Representation in Feminist Research. Sociological Research Online, 6(4), Retrieved January 2014 http://www.socresonline.org.uk/6/4/letherby.html

Lupton, Deborah (2000). 'A Love/Hate Relationship': the ideals and experiences of firsttime mothers. Fournal of Sociology, 36(1), 51-63.

Macavarish, Jan \& Billings, Jane (2010). Challenging the Irrational, amoral and antisocial construction of the 'teenage mother'. In Simon Duncan., Rosalind Edwards \& Claire Alexander (Eds.), Teenage Parenthood: What's the Problem? (pp. 47-69). London: The Tufnell Press.

Maynard, Mary (1994). Methods, Practice and Epistemology: The debate about feminism and research. In Maynard, Mary \& Jane Purvis (Eds.), Researching Women's Lives from a Feminist Perspective (pp. 10-27). London: Taylor and Francis.

Mcrobbie, Angela (2007). Top Girls? Young women and the post-feminist sexual contract. Cultural Studies, 21(4-5), 718-737. http://dx.doi.org/10.1080/09502380701279044

Mcrobbie, Angela (2009). The Aftermath of Feminism: Gender, Culture and Social Change. London: Sage.

Mercer, Jane (2007). The Challenges of Insider Research in Educational Institutions: Wielding a double-edged sword and resolving delicate dilemmas. Oxford Review of Education, 33(1), 1-17.

Millen, Dianne (1997). Some Methodological and Epistemological Issues Raised by Doing Feminist Research on Non-Feminist Women. Sociological Research Online, 2(3), Retrieved from: http://www.socresonline.org.uk/2/3/3.html

Mohammed, Robina (2001). 'Insiders' and/or 'outsiders': positionality, theory and praxis. In Melanie Limb \& Claire Dwyer (Eds.), Qualitative Methodologies for Geographers: Issues and Debates (pp. 101-120). London: Arnold.

Oakley, Ann (1981). Interviewing Women: A Contradiction in Terms. In Helen Roberts (Ed.), Doing Feminist Research (pp. 30-61). Boston: Routledge.

Pemberton, Max (2009, June 13). Teenage Pregnancy: A national talking point. The Daily Telegraph. Retrieved from:

http://www.telegraph.co.uk/health/healthadvice/maxpemberton/5794780/Tee nage-pregnancy-a-national-talking-point.html

Phoenix, Anne (1991). Young Mothers. Cambridge: Polity Press.

Pillow, Wanda (2004). Unfit Subjects: Educational Policy and the Teen Mother. New York, Routledge.

Pomerantz, Shauna., Raby, Rebecca \& Stefanik, Andrea (2013). Girls Run the World? Caught between sexism and Postfeminism in the school. Gender \& Society, 27(2), 185-207. http://dx.doi.org/10.1177/0891243212473199

Preissle, Judith (2007). Feminist Research Ethics. In Hesse-Biber Sharlene Nagy (Ed.), Handbook of Feminist Research: Theory and Praxis (pp. 515-45). London: Sage. 
Rager, Kathleen (2005). Self-care and the Qualitative Researcher: When collecting data can break your heart. Educational Researcher, 34(4), 23-27. http://dx.doi.org/10.3102/0013189X034004023

Ruddick, Sara (1993). Procreative choice for adolescent women. In Lawson, Annette \& Deborah, Rhoda (Eds.), The Politics of Pregnancy: Adolescent Sexuality and Public Policy (pp. 126-144). London: Yale University Press.

Sampson, Helen., Bloor, Michael. \& Fincham, Ben (2008). A Price Worth paying?: Considering the cost of reflexive research methods and the influence of feminist ways of 'doing'. Sociology 42(5), 919-933. http://dx.doi.org/10.1177/0038038508094570

Sandberg, Sheryl (2013). Lean In: Women, Work, and the Will to Lead. New York: Alfred A. Knopf.

Schostak, Jill \& Schostak, John (2007). Radical Research: Designing, developing and writing research to make a difference. London: Routledge.

Selman, Peter (2003). Scapegoating and Moral Panics: Teenage Pregnancy in Britain and the United States. In Sarah Cunningham-Burley \& Lynn. Jamieson (Eds.), Families and the State: Changing Relationships (pp. 159-187). Basingstoke. Palgrave Macmillan.

Social Exclusion Unit (SEU) (1999). Teenage Pregnancy Social Exclusion Unit London: Cabinet Office.

Stacey, Judith (1988). Can there be a Feminist Ethnography? Women's Studies International Forum, 11(1), 21-27. http://dx.doi.org/10.1016/02775395(88)90004-0

Toynbee, Polly (2009, February 17). Alfie's story is characteristic of New Labour's failings. The Guardian. Retrieved from: http://www.theguardian.com/commentisfree/2009/feb/17/alfie-new-labour

Wolf, Margery (1992). A Thrice Told Tale: Feminism, postmodernism, and ethnographic responsibility. Stanford, CA: Stanford University Press.

Wolf, Naomi (2004). Fire with Fire: The new female power and how to use it. New York: Random House.

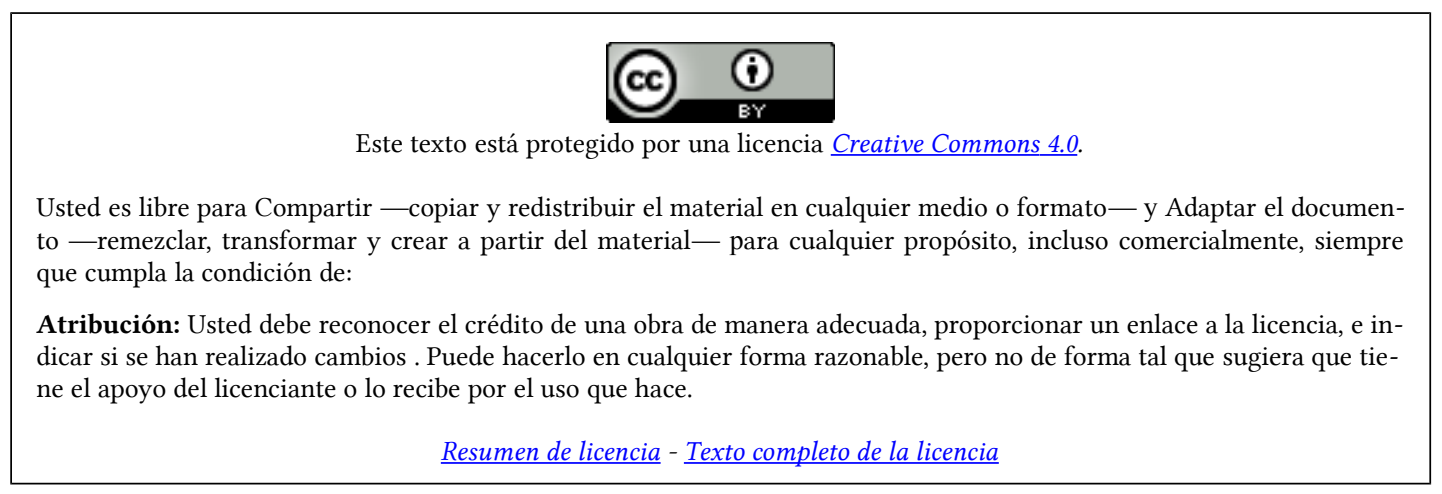

